Acta Veterinaria (Beograd), Vol. 63, No. 5-6, 665-675, 2013.

\title{
SELENIUM STATUS OF FEEDSTUFFS AND GRAZING EWES IN SERBIA
}

\author{
VALČIĆ OLIVERA, JOVANOVIĆ I, MILANOVIĆ SVETLANA and GVOZDIĆ D \\ University of Belgrade, Faculty of Veterinary Medicine, Serbia
}

(Received $1^{\text {st }}$ March 2013)

A total of 221 feedstuff samples (187 grain samples and 34 hay samples) were collected from 13 different locations on the territory of the Republic of Serbia. The results expressed as $\mu \mathrm{g} / \mathrm{kg}$ have shown an average selenium content in grain samples of $34.3 \pm 17.1$ and $53.8 \pm$ 18.7 in hay samples. However, a distinct difference was noted between samples collected fron the locations north of the river Danube (52.8 \pm 20.0 and $73.4 \pm 21.3$ for grain and hay samples, respectively) compred to the locations south of the Danube $(23.3 \pm 15.4$ and $41.7 \pm 17.1$ for grain and hay samples, respectively).

GPx activity was measured in a total of 58 blood plasma samples collected from ewes grazing on 5 different locations. The average GPX activity was $157.4 \pm 61.9 \mu \mathrm{kat} / \mathrm{L}$ and it followed a pattern similar to the distribution of Se in feedstuffs. GPx activity was higher in samples collected north of the Danube (212.8 $\pm 91.2 \mu \mathrm{kat} / \mathrm{L})$, compared to ewes south of the Danube $(66.9 \pm 14.0 \mu \mathrm{kat} / \mathrm{L})$.

According to the obtained results and literature data Serbia can be described as a selenium deficient area, showing a marked deficiency on the locations south of the Danube.

Key words: feedstuffs, glutathione peroxidase, selenium, Serbia, sheep

\section{INTRODUCTION}

Since in 1817 Berzelius discovered selenium (Se) it has been considered only for its highly toxic properties, until Schwarz and Foltz (1958) showed that in extremely small quantities it performed as an essential nutrient. Schwarz's study stimulated an astonishing amount of research on the impact of selenium in plants and animals physiology and health.

Soils and rocks are the ultimate source of all selenium in the food chain of plants and land animals. Most soils contain from 0.1 to $2 \mathrm{mgSe} / \mathrm{kg}$ (Swaine, 1955), but these values can go up to $100 \mathrm{mgSe} / \mathrm{kg}$. It is important to be able to recognize and distinguish areas of selenium deficiency, as well as toxicity. 
The estimation of selenium in localized areas can be approached by soil chemical analysis and may be used as an indicator of selenium levels in locally grown plants, or animals consuming them, but such an approach has serious drawbacks. The biological availability of selenium to plants, and subsequently to animals, depends on a number of factors such as the chemical form in which selenium is present, soil pH, mechanical soil properties (Gissel-Nielsen, 1971), and use of mineral fertilizers (Gissel-Nielsen, 1974). After absorption of selenite or selenate ions, plants synthesize selenoamino acids with selenomethionine (SeMet) representing more than $50 \%$ of the Se present in cereal grains (Olson and Palmer, 1976) with Se-methyl-selenomethionine, selenocysteine, Se-methylselenocysteine being the other selenocompounds found in plants (Brody, 1994). Plant species are another consideration as some types of plants are more efficient at absorbing selenium from the soil than others (Rosenfield and Beath, 1964). Most forage, cereal and oilmeal crop plants are non-accumulator plants containing on average less than $25 \mathrm{mgSe} / \mathrm{kg}$, dry weight do not accumulate over $100 \mathrm{mg} / \mathrm{kg}$ even when grown on seleniferous soils (Terry et al., 2000)

The need for selenium geobotanical mapping arose soon after Kubota et al. (1967) produced a detailed map of the USA which clearly defined areas where selenium toxicity or deficiency may be expected. An extensive study on more than 11,000 feedstuff samples on 1,103 locations in 28 provinces in the People's Republic of China revealed serious selenium deficiency as $25 \%$ of the tested samples contained less than $20 \mu \mathrm{gSe} / \mathrm{kg}$ (Liu et al., 1986). Geobotanical mapping of Europe has revealed areas which are deficient in selenium (Scandinavian Peninsula), as well as sporadic zones of selenium toxicity (Ireland). The situation on the Balkan Peninsula is far from ideal. Studies carried out during the 90ties revealed low selenium concentrations in cereal samples from Macedonia (Mihailović et al., 1993) and extremely low (all forage samples were below 50 $\mu \mathrm{gSe} / \mathrm{kg}$ ) in the region of south Serbia on the Pester highland.

Grazing animals, such as sheep and goats, which in extensive production settings rarely are supplemented with professionally controlled amounts of micronutrients, are the first to reflect low selenium conditions. Selenium nutrition of ruminants has some specific features, which create specific problems. Indeed, rumen bacteria incorporate selenium during protein synthesis; hence it is absorbed as selenoaminoacids.

Selenium functions within mammalian systems primarily in the form of selenoproteins. Selenoproteins contain selenium as selenocysteine and perform a variety of physiological roles. The most important identified selenoproteins include: 5 isoforms of glutathione peroxidase (GPx) selenoprotein P; iodothyronine deiodinase types 1,2 , and 3 ; selenoprotein $W$; thioredoxin reductases; and selenophosphate synthetase. The principal methods for the assessment of selenium status include the determination of its concentration and measurement of GPx activities in tissues, as well as the occurrence of selenium responsive diseases in animals. The activity of erythrocyte GPx reflects the long-standing 
selenium status of the animal, as the synthesis of the enzyme occurs only during the time of erythropoesis due to the fact that mature erythrocytes do not have the organelles needed for protein synthesis (Osame et al., 1990). Thus, whole blood GPx activity can be considered as the reflection of long-time selenium status and plasma/serum GPx activity reflects short-term changes as the distinct blood compartments reflect different time frames in the nutritional history of the animal (Waldner et al., 1998). This was moreover confirmed by van Ryssen et al. (2013) who studied the time-dependent effect of selenium supplementation on the relationship between selenium concentrations in whole blood and plasma of sheep. The authors observed that the time needed to achieve a stabilized ratio between plasma and whole blood selenium was on average 50 days, as whole blood needed a long time span in order to incorporate selenium into the erythrocytes. Wilson and Judson (1976) reported that GPx activity in the erythrocytes is more resistant to the effect of storage time than plasma GPx. Besides, Sheperd and Miller (1981) disclosed that sheep erythrocyte GPx activity is 99 times higher than in the plasma, thus confirming the previous report by Scholtz and Hutchinson (1979) who recorded that out of the total GPx activity only $0.70 \%$ is due to plasma GPx.

Glutathione peroxidase plays a major role in the protection of cells against oxidative damage by endogenous peroxides. Peroxides can damage cell membranes leading to degeneration and necrosis.

Selenium deficiency in domestic animals manifests itself in a number of disorders which result in poor health, and low productive and reproductive performances. In sheep, two selenium-responsive conditions are recognized: one is a myopathy which presents itself in lambs as white muscle disease (WMD) (Muth et al., 1958), the other is a syndrome of lowered productivity which ranges from poor wool production to clinically manifested selenium responsive unthriftiness (Drake et al., 1960).

The aim of this study was to determine selenium content in forage and cereals grown in Serbia in order to develop a geobotanical map of the region. Grazing, selenium non supplemented sheep were selected for the determination of selenium dependent GPx activity in order to detect areas of possible selenium deficiency in several agriculturally important regions.

\section{MATERIAL AND METHODS}

\section{Feedstuff samples}

Samples of feedstuffs (187 of grain and 34 of hay) were collected from 13 locations throughout Serbia, on farms belonging to local farmers. The fields were never previously treated with Se-containing fertilizers. All grain samples (wheat, corn, barley, and oats) were cleaned from foliage, stalks, roots, soil, grit and non edible parts. Hay was sampled from the central portion of the hay stack. Samples 
were stored in paper-bags at room temperature until analysis. Selenium content was determined by the fluorometric method (Lindberg, 1968)

\section{Experimental animals}

The study was conducted on 5 locations in Serbia, on a total of 58 ewes. Groups of selected animals (Wirtenberg x Cigaja crossbred sheep), were formed on each location on the basis of a common age range (3-5 years) and sex (female), multiparous, and feeding on locally grown forage and grain.

After puncture of $v$. jugularis blood samples were collected in heparinized test tubes and stored at $8^{\circ} \mathrm{C}$ for not more than $12 \mathrm{~h}$. Immediately before the measurement of GPx activity $50 \mu \mathrm{L}$ of full blood samples were hemolysed in $1 \mathrm{~mL}$ Drabkin's reagent, thus making a $21 \mathrm{x}$ dilution of hemolysate. Selenium dependent GPx activity was determined within $24 \mathrm{~h}$ from sampling. Glutathione peroxidase (GPx - EC. 1.11.1.9) activity was analyzed spectophotometrically by the coupled test (Günzler et al., 1974) using a concentration of tertiary butyl hydroperoxide (TBH) below $2.32 \mathrm{mM}$ in order to measure only the activity of selenium dependent GPx (Sankari and Atroshi, 1983).

\section{RESULTS}

Selenium concentrations in feedstuffs sampled on a total of 13 locations in Serbia are shown in Table 1. The average selenium content in grain and hay samples in Serbia was $34.3 \pm 17.1 \mu \mathrm{gSe} / \mathrm{kg}$, and $53.8 \pm 18.8 \mu \mathrm{gSe} / \mathrm{kg}$, respectively. The highest concentration of selenium $(52.8 \pm 20.0 \mu \mathrm{gSe} / \mathrm{kg})$ in grains was determined in the samples collected on locations north of the river Danube. In this region the highest value was recorded in Melenci $(60.0 \pm 21.0 \mu \mathrm{gSe} / \mathrm{kg})$, and lowest in Vršac(44.1 $\pm 33.0 \mu \mathrm{gSe} / \mathrm{kg})$. Selenium content in hay samples showed marked differences and ranged from $104.6 \pm 20.0 \mu \mathrm{gSe} / \mathrm{kg}$ on location Bačka Topla to $46.6 \pm 15.9 \mu \mathrm{gSe} / \mathrm{kg}$ in Apatin. The average selenium content in hay samples collected north of the river Danube $(73.4 \pm 21.3 \mu \mathrm{gSe} / \mathrm{kg})$ was higher compared to the locations south of the Danube $(41.7 \pm 17.2 \mu \mathrm{gSe} / \mathrm{kg})$.

In Central Serbia the concentration of selenium in feedstuffs was markedly lower $(23.3 \pm 15.4 \mu \mathrm{gSe} / \mathrm{kg})$, ranging from $4.3 \pm 1.0 \mu \mathrm{gSe} / \mathrm{kg}$ in grain samples on the Sjenica location to $26.0 \pm 21.4 \mu \mathrm{gSe} / \mathrm{kg}$ on location Šabac.

The average GPx activity in ewes whole blood sampled on five locations in Serbia was $157.4 \pm 61.9 \mu \mathrm{kat} / \mathrm{L}$. GPx activity was higher in the samples taken from ewes grazing north of the Danube compared from samples on locations south of the Danube (Table 2.) The lowest recorded activities were in whole blood samples from the location Aleksinac $(65.4 \pm 11.1 \mu \mathrm{kat} / \mathrm{L})$. 
Table 1. Selenium content $(\mu \mathrm{g} / \mathrm{kg})$ in grain and hay feedstuff samples in Serbia

\begin{tabular}{|c|c|c|c|c|}
\hline Location & Gra & & \multicolumn{2}{|c|}{ Hay $(\mu \mathrm{g} / \mathrm{kg})$} \\
\hline \multicolumn{5}{|c|}{ North of Danube } \\
\hline Subotica & $58.3 \pm 18.6$ & $(n=11)$ & & \\
\hline Bačka Topola & $47.2 \pm 17.0$ & $(n=25)$ & $104.6 \pm 20.0$ & $(n=5)$ \\
\hline Apatin & $51.2 \pm 27.1$ & $(n=11)$ & $46.6 \pm 15.9$ & $(n=5)$ \\
\hline Melenci & $60.0 \pm 21.0$ & $(n=4)$ & & \\
\hline Zrenjanin & $59.0 \pm 13.0$ & $(n=4)$ & & \\
\hline Vršac & $44.0 \pm 33.0$ & $(n=4)$ & $66.2 \pm 31.6$ & $(n=3)$ \\
\hline Futog & $58.9 \pm 18.5$ & $(n=11)$ & & \\
\hline North & $52.8 \pm 20.0$ & $(n=70)$ & $73.4 \pm 21.3$ & $(n=13)$ \\
\hline \multicolumn{5}{|c|}{ South of Danube } \\
\hline Ruma & $36.8 \pm 16.7$ & $(n=17)$ & $66.4 \pm 30.3$ & $(n=3)$ \\
\hline Šabac & $26.0 \pm 21.4$ & $(n=24)$ & & \\
\hline Smederevo & $18.9 \pm 13.4$ & $(n=54)$ & $45.9 \pm 21.6$ & $(n=8)$ \\
\hline Zajačar & $25.8 \pm 18.7$ & $(n=9)$ & $42.0 \pm 13.3$ & $(n=6)$ \\
\hline Kraljevo & $24.9 \pm 12.9$ & $(n=8)$ & & \\
\hline Sjenica & $4.3 \pm 1.0$ & $(n=5)$ & $14.4 \pm 4.0$ & $(n=4)$ \\
\hline South & $23.3 \pm 15.4$ & $(n=117)$ & $41.7 \pm 17.1$ & $(n=21)$ \\
\hline SERBIA & $34.3 \pm 17.1$ & $(n=187)$ & $53.8 \pm 18.7$ & $(n=34)$ \\
\hline
\end{tabular}

Table 2. Whole blood glutathione peroxidase activity ( $\mu \mathrm{kat} / \mathrm{L}$ ) in ewes in Serbia, according to location

\begin{tabular}{|c|c|c|}
\hline Location & \multicolumn{2}{|c|}{ GPx ( $\mu$ kat/L) } \\
\hline \multicolumn{3}{|c|}{ North of Danube } \\
\hline Kać & & \\
\hline Zrenjanin & $236.5 \pm 85.7$ & $(n=15)$ \\
\hline Čoka & $194.0 \pm 101.1$ & $(n=14)$ \\
\hline North & $212.8 \pm 91.2$ & $(n=36)$ \\
\hline \multicolumn{3}{|c|}{ South of Danube } \\
\hline $\mathrm{Ub}$ & $70.2 \pm 20.2$ & $(n=7)$ \\
\hline Aleksinac & $65.4 \pm 11.1$ & $(n=15)$ \\
\hline South & $66.9 \pm 14.0$ & $(n=22)$ \\
\hline SERBIA & $157.4 \pm 61.9$ & $(n=58)$ \\
\hline
\end{tabular}




\section{DISCUSSION}

Serbia comprises two main geochemical areas. One extends south of the river Danube and has large deposits of lead, zinc, antimony and copper. The other one extends north of the Danube (Vojvodina) and consists of quaternary sediments. For the genesis and development of agricultural soil in Vojvodina loess is the most widespread parental substrate. Loess provides the basis for the most important soil type in this region - chernozem. Loess in Vojvodina contains 20$30 \%$ of $\mathrm{CaCO}_{3}$, which gives it an advantage over the loess in Eastern Europe (Živković, 1971). Such a favorable geological soil composition and $\mathrm{pH}$ is reflected in a more efficient selenium uptake by plants and a higher selenium concentration in plants (Fordyce et al., 2000).

In the here described study the obtained results clearly indicate that the analyzed grain samples $(n=68)$ collected on locations north of the Danube contained about twice as much selenium as the other geochemical areas. A similar observation was made by Klapec et al. (2004) regarding selenium content in vegetable samples collected in Croatia. The authors recorded a tendency of higher levels in samples from the river Sava basin, compared to the Drava basin, as the mean concentration of selenium was three times higher (114.2 $\pm 80.0 \mathrm{vs}$. $38.1 \pm 1.0 \mu \mathrm{g} / \mathrm{kg}$ ). Bratakos and lannou (1989) tested 96 different locations in Greece and reported average selenium concentration in corn and wheat $120 \pm$ 80 and $290 \pm 190 \mu \mathrm{g} / \mathrm{kg}$, respectively. Smrkolj et al. (2005) studied the selenium content in selected Slovenian foodstuffs, and reported an average selenium content of $11.9 \mu \mathrm{g} / \mathrm{kg}$ in wheat samples. Serdaru et al. (2003) examined the selenium status of 185 feeding stuff samples (hay, green plants and feedstuff concentrates) cultivated in south-west Romania. Only $6.5 \%$ of the samples contained an appropriate selenium content $(150-300 \mu \mathrm{g} / \mathrm{kg})$, while $93.5 \%$ of the samples were selenium deficient with a selenium content range of $1-150$ $\mu \mathrm{g} / \mathrm{kg}$. Adams et al. (2002) conducted a survey on 452 grain samples of bread making wheat produced in the UK and reported a mean concentration of $32 \mu \mathrm{g} / \mathrm{kg}$. Comparable selenium concentrations in grains were reported in other European countries (Tamás et al., 2010). In general, European grains contain lower levels of selenium than North American samples. Very low selenium concentrations have been reported in Scandinavian countries with concentrations ranging $7-18 \mu \mathrm{g} / \mathrm{kg}$ (Gissel - Nielsen, 1984).

Walnik et al. (1983) reported a range of $10-5300 \mu \mathrm{gSe} / \mathrm{kg}$, with a mean value of $160 \mu \mathrm{g} / \mathrm{kg}$ for 290 wheat samples collected from major growing areas in USA. Comparable results were reported for Canada and Australia (Boila et al., 1993; Lyons et al., 2005).

All the above cited reports should be viewed under the light of nutritional requirements. The nutritional minimum level both for animals and humans is about 50 - $100 \mu \mathrm{gSe} / \mathrm{kg}$ in dry fodder/food, and intake below may cause selenium deficiency (Gissel - Nielsen, 1984). The National Research Council (NRC, 1985) 
proposed the recommended minimal selenium concentrations in feedstuffs for sheep to be $100 \mu \mathrm{gSe} / \mathrm{kg}$ The average selenium concentrations on each of the sampled locations south of the river Danube is below the minimum NRC recommended levels (Table 1). Tested grain samples grown in the Vojvodina region are marginally selenium deficient (mean concentrations ranging from 60.0 $\mu \mathrm{g} / \mathrm{kg}$ in Melenci to $44.0 \mu \mathrm{g} / \mathrm{kg}$ in Vršac). The results obtained in our study are close to the results obtained by Šovljanski et al. (1991) who reported an average selenium concentration in wheat samples in Vojvodina in the range $50-60 \mu \mathrm{g} /$ $\mathrm{kg}$, and in Zaječar $(36 \mu \mathrm{g} / \mathrm{kg})$. The Sjenica plateau is dramatically selenium deficient with an average content of selenium in barley samples as low as $2 \mu \mathrm{g} / \mathrm{kg}$ (Mihailović et al., 1996). These results being comparable to the values obtained in this study $(4.3 \mu \mathrm{g} / \mathrm{kg})$.

Based in extensive previous studies in China, Tan and Huang (1991) proposed the following ranges of grain selenium concentrations: below $25 \mu \mathrm{g} / \mathrm{kg}$ deficient, $25-40 \mu \mathrm{g} / \mathrm{kg}$ marginal, $40-1000 \mu \mathrm{g} / \mathrm{kg}$ moderate to high, and above $1000 \mu \mathrm{g} / \mathrm{kg}$ excessive.

The absence of an existing pattern in selenium distribution in forage samples (Table 1) can be attributed to the heterogeneity of the botanical composition of the samples and differences in soil selenium uptake by plants. Pešut (1995) reported values for selenium concentration in alfalfa hay samples to be almost double compared to meadow hay sampled from the same region $(70.79 \pm 44.35$ and $39.07 \pm 18.20 \mu \mathrm{gSe} / \mathrm{kg}$, respectively).

In Serbia in 2011 there was a total of 1.460 .000 sheep, however the number is on the decrease as in 1991 a total of 2.127 .000 sheep were recorded. The demand for meat is on the increase and production should be improved not only by increasing the number of animals, but by improving the zootechnical protocols, too. In order to determine the presence of nutritional selenium deficiency in sheep, and thus eventual losses due to unthriftiness and poor reproduction a survey on the selenium status of grazing sheep was carried out in our study.

The concentration of selenium in whole blood, plasma/serum and the liver of animals, as well as GPx activity is widely used by laboratories to predict the selenium status of animals (Gerloff, 1992). It is recognized that the information provided by whole blood selenium status represents an altogether different time frame in the nutritional history of the animal, as selenium is incorporated in the erythrocytes at the time of erythropoesis (Nicholson et al., 1991). Pavlata et al. (2012) assessed the correlation between the activity of GPx and the selenium concentrations in the whole blood of sheep, in order to calculate by linear regression analysis the activity of GPx corresponding to selenium concentrations between 70 and $100 \mu \mathrm{gSe} / \mathrm{L}$ whole blood. This interval is regarded as the reference value for sheep. The obtained results showed a high correlation between selenium status and GPx activity $\left(R^{2}=0.90\right)$. The authors (Pavlata et al., 2000; Scholz and Stober, 2002) previously described three stages of evaluation: adequate (higher than 100 $\mu \mathrm{gSe} / \mathrm{L}$ whole blood) marginal, $(70-100 \mu \mathrm{gSe} / \mathrm{L})$ and deficient (less than 70 
$\mu \mathrm{gSe} / \mathrm{L})$. The strongest correlation was found for selenium blood values below 70 $\mu \mathrm{gSe} / \mathrm{L}$, and the correlation between selenium concentration and GPx becomes less significant with higher selenium concentrations.

The results for GPx activity presented in Table 2 clearly show a pattern similar to the measured concentrations of selenium in grain samples. Regions with a higher selenium content in feedstuffs (north of the river Danube) reflected higher activities in whole blood GPx (Belo Blato $236.51 \pm 85.72 \mu \mathrm{kat} / \mathrm{L}$; Temerin199.5 $\pm 83.24 \mu \mathrm{kat} / \mathrm{L}$; Čoka $194 \pm 101.07 \mu \mathrm{kat} / \mathrm{L})$. However, these values are far lower than recommended by Pavlata et al. (2012) as the authors measured the whole blood GPx activity to be in the range 409 - $637 \mu \mathrm{kat} / \mathrm{L}$ for marginal selenium blood concentration (70 - $100 \mu \mathrm{gSe} / \mathrm{L})$. Thus it can be concluded that the feedstuffs grown in the Vojvodina region cannot result in adequate blood selenium concentrations which would ensure an activity of GPx close to $600 \mu \mathrm{kat} / \mathrm{L}$. Whole blood GPx activity measured on the other locations (Ub and Aleksinac) in Serbia are low $(70.21 \pm 20.15 \mu \mathrm{kat} / \mathrm{L}$ and $65.4 \pm 11.9 \mu \mathrm{kat} / \mathrm{L}$, respectively). Such values are in agreement with the report published by Hudman et al. (1988) that at GPx activities below $165 \mu \mathrm{kat} / \mathrm{L}$ deficiency signs, such as unthriftiness and nutritive muscular dystrophy (WMD) in lambs can be expected. The same group of authors described cases of WMD in cases where the GPx activity was $385 \mu \mathrm{kat} / \mathrm{L}$, thus indicating to the need for additional prudence when estimating selenium deficiency only according to the presence of this disease.

\section{ACKNOWLEDGEMENT}

This work was supported by the Ministry of Science and Technology of Serbia, Grant No TR 31003 and Grant No TR 31050.

Address for correspondence:

Prof dr Olivera Valčić

Department of Physiology and Biochemistry

Faculty of Veterinary Medicine, University of Belgrade.

Bulevar Oslobodjenja 18

11000 Belgrade, Serbia

Email: olja@vet.bg.ac.rs

\section{REFERENCES}

1. Adams ML, Lombi E, Zha FJ, McGrath SP, 2002, Evidence of low selenium concentrations in UK bread-making wheat brain, J Sci Food Agric, 82, 1160-5.

2. Boila RJ, Stothers SC, Campbell LD, 1993, The concentration of selenium in the grain from wheat, barley and oats grown at selected locations throught Manitoba, Can J Anim Sci, 73, 217-21.

3. Bratakos MS, loannou PV, 1989, The regional distribution of selenium in Greek cereals, Sci Total Environ, 84, 237-47.

4. Brody $T, 1994$, Nutritional biochemistry, Academic Press, Inc: New York, NY. 
5. Drake C, Grant $A B$, Hartley $W H, 1960$, Selenium in animal health, 2, The effect of selenium in unthrifty, weaned lambs, $N Z$ Vet J, 8, 7-10.

6. Fordyce FM, Zhang GD, Green K, Liu XP, 2000, Soil, grain and water chemistry in relation to human selenium - responsive diseases in Enshi district, Appl Geochem, 15, 117-32.

7. Gerloff BJ, 1992, Effect of selenium supplementation on dairy cows, J Anim Sci, 70, 3934-40.

8. Gissel-Nielsen $\mathrm{G}, 1971$, Influence of $\mathrm{pH}$ and texture of the soil on plant uptake of added selenium, J Agr Food Chem, 19, 1165.

9. Gissel-Nielsen G, 1974, Effect of fertilization on uptake of selenium by plants, In: Plant Analysis on Fertilizer Problems, Proceedings of the International Colloquium on Plant Analysis and Fertilizer Problems, Hanover, W Germany, Vol 1, 111.

10. Gissel-Nielsen G, Gupta UC, Lamand M, Westermarck T, 1984, Selenium in soils and pants and its importance in livestock and human nutrition, Adv Agr, 37, 397-460.

11. Günzler WA, Kremers H, Flohe L, 1974, An improved coupled test procedure for glutathione peroxidase (E.C. 1.11.1.9) in blood, Z Klin Chem Klin Biochem, 12, 444.

12. Hudman, JF, Costa ND, Robinson WF, 1988, An apparent phosphate selenium interaction in weaner sheep, J Trace Elem Electrolytes Health Dis, 2, 2, 105.

13. Klapec T, Mandić LM, Grgić J, Primorac Lj, Perl A, Krstanović V, 2004, Selenium in selected foods grown or purchased in eastern Croatia, Food Chem, 85, 445-52.

14. Kubota J, Allaway WH, Carter DL, Cary EE, Lazar VA, 1967, Selenium in crops in the United States in relation to selenium-responsive diseases of animals, J Agr Food Chem, 15, 3, 448-53.

15. Lindberg $S, 1968$, Selenium determination in plant and animal material, and water, A methodological study, Acta Vet Scand Suppl, 23, 1-41.

16. Liu CH, Lu ZH, Su Q, Duan YQ, 1986, Regional selenium deficiency of feeds in China, In: Proceedings of the Third International Symposium on Selenium in Biology and Medicine, Combs GFJ, Spallholz JE, Levander OA and Oldfield JE, Avi Publ Co, Westport, Conn.

17. Lyons GH, Genc Y, Stangoulis JCR, Palmer LT, Graham RD, 2005, Selenium distribution in weath grain, and the effect of postharvest processing on wheat selenium content, Biol Trace Elem Res, 103, 155-68.

18. Mihailović M, Kuzmanovski D, Črčev D, Jovanović I, Ledina O, Veličkovski S, 1993, Selenium status in cerials and selenium status of ewes and goats in Macedonia, 2 International summer conference for advancement of sheep and goat production, 100.

19. Mihailović M, Lindberg P, Jovanović IB, 1996, Selenium content in feedstuffs in Serbia, Acta Vet (Belgrade), 46, 5-6, 343-8.

20. Muth O, Oldfield J, Remmert L, Shubert J, 1958, Effects of selenium and vitamin E on white muscle disease, Science, 128, 1090.

21. National Research Council, 1985,Nutrient requirements of sheep, National Academy Press, 6th rev ed, Washington DC.

22. Nicholson JEG, Allen JG, Bush BS, 1991, Comparison of responses of whole blood and plasma selenium levels during selenium depletion and repletion of growing cattle, Can J Anim Sci, 71, 925 - 9.

23. Olson OE, Palmer IS, 1976, Selenoamino acids in tissues of rats administered inorganic selenium, Metabolism, 25, 299-306.

24. Osame S, Ohtani T, Itchio S, 1990, Studies on serum tocopherol and selenium levels and blood glutathione peroxidase activities in lambs with White Muscle Disease, Jpn J Vet Sci, 52, 705-10.

25. Pavlata L, Misurova L, Pechova A, Husakova T, Dvorak R, 2012, Direct and indirect assessment of selenium status in sheep - a comparison, Vet Med, 57, 5, 219-23.

26. Pavlata L, Pechova A, Illek J, 2000, Direct and indirect assessment of selenium status in cattle - a comparison, Acta Vet Brno, 69, 281 - 7.

27. Pešut $O, 1995$, Selenium content in feedstuffs and sellenium status of sheep in the Bačka region, Master Thesis, University of Belgrade, Belgrade. 
28. Rosenfeld I, Beath OA, 1964, Selenium: Geobotany, Biochemistry, Toxicity and Nutrition, Academic Press, New York.

29. Sankari S, Atroshi F, 1983, Effect of dietary selenium on erythrocyte glutathione peroxidase and blood selenium in two types of Finnisheep genetically selected for high and low glutathione peroxidase activity, Zbl Vet Med A, 30, 452.

30. Scholz RW, Hutchinso LJ, 1979, Distribution of glutathione peroxidase activity and selenium in the blood of diary cows, $A m J$ Vet Rec, 40, 2, 245.

31. Scholz H, Stober M, 2002, Enzootic myodystrophia in preruminant calves, In: Internal Medicine and Surgery in Cattle in German, Parey Buchverlag, Berlin, 1000-4.

32. Schwartz K, Folz CM, 1958, Factor 3 activity of selenium compounds, J Biol Chem, 233, 245.

33. Serdaru M, Vladesku L, Avram N, 2003, Monitoring of feed selenium in a southeast region of Romania, J Agric Food Chem, 51, 16, 4727-31.

34. Shepard, $A D$, Miller KR, 1981, Stability of GSH-Px in ovine blood samples under various storage conditions and response of this enzyme to different methods of selenium supplementation, $N Z$ Vet $J, 29,77$,

35. Smrkolj P, Pograjc L, Hlastan-Ribič C, Stibilj V, 2005, Selenium content in selected Slovenian feedstuffs and estimated daily intake of selenium, Food Chem, 90, 691-7.

36. Swaine J, 1955, The trace element content of soils, Commonwealth Bureau of Soil Sci Tech Comm, 48, 1-157.

37. Šovljanski R, Lazić S, Obradović S, Beker D, 1991, Sadržaj teških metala, selena i ostaci organohlornih insekticida u pšenici, žito-hleb, 18, 17.

38. Tamás M, Mándoki Zs, Csapó J, 2010, The role of selenium content of wheat in the human nutrition, A literature review, Acta Univ Sapientiae, Alimentaria, 3, 5-34.

39. Tan JN, Huang YJ, 1991, Selenium in geo-ecosystem and its relation to endemic diseases in China, Water Air Soil Pollut, 57-58, 59-68.

40. Terry N, Zajed AM, De Souza MP, Tarun AS, 2000, Selenium in higher plants, Annu Rev Plant Physiol Mol Biol, 51, $401-2$.

41. Van Ryssen, Coertze RJ, Smith MF, 2013, Time-dependent effect of selenium supplementation on the relationship between selenium concentrations in whole blood and plasma of sheep, Small Rum Res, 112, 85-99.

42. Waldner C, Campbell J, Jim GK, Guichon PT, Booker C, 1998, Comparison of 3 methods of selenium assessment in cattle, Can Vet $J, 39,225-31$.

43. Wilson PS, Judson GJ, 1976, Glutathione peroxidase activity in bovine and ovine erythrocytes in reletion to blood selenium concentration, $B r$ Vet $J, 132,428$.

44. Wolnik KA, Fricke FL, Capar SG, Braude GL, Meyer MW, Satzger RD et al, 1983, Elements in major raw agricultural crops in the United States. 2. Other elements in lettuce, peanuts, potatoes, soybeans, sweet corn, and wheat, J Agric Food Chem, 31, 1224-49.

45. Živković B, Nejgrbauer V, Tanasijević $Đ$, Milković N, Stojković L, Drezgić $P$, 1971, In: Zemljišta Vojvodine, Institut za poljoprivredna istraživanja, Novi Sad, 32-46. 


\section{STATUS SELENA U HRANIVIMA ZA OVCE NA ISPAŠI U SRBIJI}

VALČIĆ OLIVERA, JOVANOVIĆ I, MILANOVIĆ SVETLANA i GVOZDIĆ D

\section{SADRŽAJ}

Ispitano je ukupno 221 uzoraka biljnih hraniva (187 žitarica i 34 uzoraka sena) sakupljenih sa različitih lokacija na područiju 15 opština Republike Srbije. Rezultati izraženi u $\mu \mathrm{g} / \mathrm{kg}$ pokazali su da je prosečan sadržaj selena $34.3 \pm 17.1$ $\mu \mathrm{g} / \mathrm{kg}$ u uzorcima žitarica i $53.8 \pm 18.7 \mu \mathrm{g} / \mathrm{kg}$ u uzorcima sena. Međutim, značajna razlika je uočena između uzoraka koji potiču sa područja severno (52.8 \pm 20.0 i $73.4 \pm 21.3$ za uzorke žitarica i sena) u odnosu na uzorke sa južne strane toka Dunava (23.3 \pm 15.4 i $41.7 \pm 17.1$ za uzorke žitarica i sena).

Aktivnost GPx je merena u ukupno 58 uzoraka krvne plazme ovaca koje su bile na ispaši na 5 različitih lokacija. Prosečna GPx aktivnost je iznosila 157.4 $\pm 61.9 \mu \mathrm{kat} / / \mathrm{L}$. Aktvnost GPx je pokazala distribuciju po lokalitetima slično kao i ispitivana biljna hraniva. Naime, aktivnost GPx je bila viša $(212.8 \pm 91.2 \mu \mathrm{kat} / \mathrm{L}) \mathrm{u}$ uzorcima krvi ovaca na ispaši severno od Dunava u odnosu na ovce koje su bile na ispaši na južnim lokalitetima (66.9 $\pm 14.0 \mu \mathrm{kat} / \mathrm{L})$.

U skladu sa postignutim rezultatima, kao i literaturnim podacima, Srbija može da se svrsta u seleno deficitarne regione, pri čemu lokaliteti južno od toka Dunava pokazuju više izražen deficit. 